\title{
WHAT FACTORS AFFECT THE QUALITY OF LIFE OF PATIENTS WITH KELOIDS?
}

\author{
Fabianne Furtado ${ }^{*}$, Bernardo Hochman ${ }^{2}$, Soraia Francisco Ferrara ${ }^{3}$, Gal Moreira Dini ${ }^{4}$, José Mário Camelo-Nunes ${ }^{5}$, Yara Juliano ${ }^{6}$, Lydia Masako \\ FERREIRA $^{7}$
}

Trabalho realizado no Programa de Pós-Graduação em Cirurgia Plástica da Universidade Federal de São Paulo - UNIFESP, São Paulo, SP

\author{
*Correspondência: \\ Rua Napoleão de Barros, \\ No $715-4^{\circ}$ andar - Vila \\ Clementino \\ São Paulo - SP \\ CEP: 04024-002 \\ E-mail: bibifst@yahoo.com.br \\ Telefone: (11) 5539-0824 \\ Fax: (11) 5571-6579
}

\begin{abstract}
SUMMARY
OBJective. To evaluate factors that affect the quality of life (QoL) of patients with keloids.

Methods. A study was conducted on 102 patients of both genders between 15 and 70 years old. During initial evaluation, clinical factors, such as keloid visibility, duration and evolution of the disease, previous treatments, types of treatments and recurrence were recorded. Later, patients responded to the QualiFibro questionnaire, which is specific for evaluation of the QoL of patients with keloids and comprises the physical and psychological domains, and six visual numeric scales (VNS), of which three are related to psychological factors (satisfaction with appearance, shame of the disease, and suffering experienced), and the other three are related to physical factors (pruritus, pain and movement restriction).

RESULts. Patients with keloids on non-visible areas of the body $(p<0.01)$ and more than 10 years of disease $(p<0,049)$ reported higher scores on the physical domain of the QualiFibro questionnaire, indicating increased severity compared with patients with keloids on visible areas of the body and disease duration of less than 10 years. There was a positive correlation between psychological (satisfaction with appearance, feelings of embarrassment about the disease and suffering experienced) and physical factors (pruritus, pain and movement restriction) evaluated using the VNSs, and both domains of the QualiFibro questionnaire.

Conclusion. Results indicate that the physical domain of the QualiFibro questionnaire was the most affected in patients with keloids on non-visible areas and in those with keloids for more than 10 years. Psychological and physical factors associated with keloids as assessed with the VNS affected both psychological and physical domains of QoL.
\end{abstract}

KEY wORDS: Keloid. Quality of life. Questionnaires.

\section{INTRODUCTION}

Currently, patients with chronic cutaneous disease are not a part of the archetypes amendable to society ${ }^{1}$. Therefore, in addition to physical aftermaths, these patients present psychosocial co-morbity².

Due to the impact caused by chronic cutaneous disease on people's quality of life (QoL), this subject has been constantly mentioned for at least 10 years ${ }^{3,4}$. Among those researched are psoriasis $^{5,6}$, acne vulgaris ${ }^{7}$, atopic dermatitis ${ }^{8,9}$ and vitiligo ${ }^{10}$, denominated phychodermatosis ${ }^{11}$.

Even though keloids are included in the category of chronic cutaneous disease and present high prevalence among
Afro-descendents, Asians and Hispanics ${ }^{12}$, only recently Bock et al. ${ }^{13}$ developed the first questionnaire to assess the QoL of these individuals. This questionnaire represented a landmark in the assessment on how keloids affect QoL. Until now, regardless of the anesthetic esthetic, and sometimes disfiguring character, analysis of the extension and severity of keloids by a specialist, in a simple way, focused on signs and symptoms such as hyperemia, growth, pain and pruritus. However, it has already been shown that evaluation by specialists does not necessarily relate to how the patient perceives his/her condition ${ }^{14}$.

Simple and accurate measurements, such a the QoL questionnaires can provide information on the psychosocial

1. Mestrado - Aluna do Programa de Pós-Graduação em Cirurgia Plástica da Universidade Federal de São Paulo - UNIFESP (Nível: Doutorado), São Paulo,SP

2. Doutorado - Professor Orientador do Programa de Pós-Graduação em Cirurgia Plástica da Universidade Federal de São Paulo - UNIFESP, São Paulo,SP

3. Aluna do Programa de Pós-Graduação em Cirurgia Plástica da Universidade Federal de São Paulo - UNIFESP, São Paulo,SP

4. Doutorado - Professor Orientador do Programa de Pós-Graduação em Cirurgia Plástica da Universidade Federal de São Paulo - UNIFESP, São Paulo,SP

5. Doutorado - Professor Co-orientador do Programa de Pós-Graduação em Cirurgia Plástica da Universidade Federal de São Paulo - UNIFESP, São Paulo,SP

6. Doutorado - Professora Titular da Faculdade de Medicina da Universidade de Santo Amaro - UNISA, São Paulo,SP

7. Livre-docência - Coordenadora do Programa de Pós-Graduação em Cirurgia Plástica da Universidade Federal de São Paulo - UNIFESP, São Paulo,SP 
factors involved in the disease. Further, they allow the patient to make decisions about the procedure to be taken, according to the autonomy principle established by Bioethics.

Recognizing an individual as a biopsychosocial model implies a holistic approach. It is well known that these physical and psychological factors are part of this context. Nevertheless, the actual influence of each of these factors on the QoL remains unknown. Thus, the objective of this study is to assess which factors influence the quality of life of patients with keloids.

\section{Methods}

This study is cross-sectional analytical with a consecutive sampling process carried out at the outpatient unit of the Plastic Surgery Course at the Federal University of Sao Paulo (UNIFESP). All individuals were included after understanding the objective of the study and signing a term of free and informed consent.

Patients with keloids from both genders were selected; with no skin color distinction, from 17 to 70 years of age. Those with less than a basic education ( $5^{\text {th }}$ grade), under any type of treatment for keloids at the time of evaluation, or with cognitive or intellectual impairment were excluded.

At initial evaluation, during anamnesis, data referring to clinical factors such as keloid visibility, disease evolution period, previous treatment (yes or no), types of treatment (none, conservative, surgical or both) and post-surgical recurrence (yes or no) were registered. Visible keloids were located on the head, forearm and leg, as mentioned by Bock ${ }^{3}$. Considering multiple lesions, questions focused on those more upsetting referred by the patient. Patients completed the QualiFibro questionnaire (attachment 1), translated into Portuguese and culturally adapted to the Brazilian context by Furtado ${ }^{15}$, following criteria established by Guillemin et al. ${ }^{16}$. It was self-applied and consisted of 15 items. Fourteen of them were distributed in two domains: psychological and physical. Items no 3, 5, 7, 9, 10, 11 , 12, 13 and 14 refer to the psychological domain. The physical domain consists of items no $1,2,4,6$, and 8 . Item 15, which refers to the intention to commit suicide, does not belong to either domain. According to the reply, each item was given the following value: $-5,-3,0-1,1,3$ or 5 . The score was the arithmetic average of items which comprised each domain. For evaluation of psychological factors (satisfaction with appearance, shame of the disease and suffering experienced) and physical (pruritus, pain and movement restriction) each patient replied to six numerical visual scales (NVS) from 0 to 10 , where 0 represents the best state (extremely satisfied with the appearance, not ashamed of the disease, no pain suffered due to the disease, no itching, no pain and no difficulty to move and 10 , the worst (completely unsatisfied with appearance, extreme shame, extreme suffering, unbearable itching, unbearable pain and great difficulty to move).

\section{Statistical analysis}

For statistical analysis of visibility, previous treatment and recurrence in the QualiFibro questionnaire score, the
Mann-Witney ${ }^{17}$ analysis was applied. For analysis of disease duration and type of treatment in QualiFibro questionnaire score, the Kruskal Wallis ${ }^{17}$ variance analysis was used. The Spearmam ${ }^{17}$ correlation was used to compare the NVS score with the questionnaire domains. The level of rejection of the null hypothesis was $\mathrm{p}<0.05$ or $5 \%$.

\section{RESULTS}

The present study consisted of 102 patients (62 women and 40 men), 74 were Afro-descendant (68,6\%), average age 27.2 years old ( \pm 10.7 years), $72,5 \%$ of the individuals were up to 30 years old. Evolution time for keloids was 5.1 years. Forty five keloids $(44,1 \%)$ were in visible areas $(82 \%$ in the earlobe) and $28(27,5 \%)$ were recurrent. From the 57 non-visible keloids, $31(54,3 \%)$ were located in the presternal area. Of the total number of patients, 46 (45,9\%) have already undergone some kind of treatment.

In relation to visibility, there was a statistically significant difference in the physical domain score of the QualiFibro questionnaire for patients with non-visible keloids $(p<0.01)$ (Table 1). Patients with keloids for more than 10 years have also presented a significantly higher score in the physical domain $(p<0.049)$ (Table 1). There was no significant difference in relation to other clinical factors (previous treatment, types of treatment and recurrence).

Correlations are in Table 1. There was significant correlation between the questionnaire's physical and psychological domains and the NVS psychological and physical factors $(p<0.01)$.

\section{Anexo 1- Questionário QualiFibro/Cirurgia Plástica - UNIFESP}

- Mudanças do clima afetam muito minhas cicatrizes (dor, sensação de tensão).

- Minhas cicatrizas restringem (dificultam) meus movimentos.

- Consigo ignorar o jeito com que as pessoas me olham por causa das minhas cicatrizes.

- A coceira em minhas cicatrizes me incomoda frequentemente.

- Devido às minhas cicatrizes, às vezes tenho vergonha de ser sexualmente ativo.

- Acho difícil aguentar a coceira em minhas cicatrizes.

- Faço o possível para evitar que pessoas próximas a mim saibam que tenho cicatrizes.

- Quando minhas cicatrizes coçam, não consigo ficar sem coçá-las.

- Não me sinto fisicamente atraente ou sexualmente desejável quando penso em minhas cicatrizes.

- Acho difícil aceitar minhas cicatrizes.

- Não vou à piscina ou à praia porque outras pessoas podem sentir nojo de minhas cicatrizes.

- Nunca me sinto embaraçado(a) ou envergonhado(a) por causa das minhas cicatrizes.

- Tenho menos autoconfiança por causa das minhas cicatrizes.

- Não me sinto bem quando me perguntam sobre minhas cicatrizes.

- Já pensei em cometer suicídio por causa das minhas cicatrizes.

Respostas: $-5=$ completamente falso; $-3=$ falso; $-1=$ até certo ponto verdadeiro; $1=$ quase verdadeiro; $3=$ verdadeiro; $5=$ completamente verdadeiro 
Table 1 - QualiFibro questionnaire score according to clinical factors: visibility, previous treatment, recurrence, disease evolution time and previous treatment

\begin{tabular}{|c|c|c|}
\hline & \multicolumn{2}{|c|}{ QualiFibro } \\
\hline & $\begin{array}{l}\text { Physical Domain } \\
\text { (mean) }\end{array}$ & $\begin{array}{c}\text { Psychological } \\
\text { Domain } \\
\text { (mean) }\end{array}$ \\
\hline \multicolumn{3}{|l|}{ Visibility } \\
\hline Visible & -1.15 & -0.72 \\
\hline Non- visible & $0.35^{*}$ & 0.00 \\
\hline \multicolumn{3}{|l|}{ Previous } \\
\hline treatment & 0.07 & -0.34 \\
\hline Yes & -0.61 & -0.30 \\
\hline \multicolumn{3}{|l|}{ No } \\
\hline \multicolumn{3}{|l|}{ Recurrence } \\
\hline Yes & 0.11 & -0.54 \\
\hline No & 0.46 & -0.24 \\
\hline \multicolumn{3}{|l|}{ Disease evolution } \\
\hline$<1$ year & 0.48 & -0.20 \\
\hline $1-2$ years & -0.82 & -0.64 \\
\hline 2.1-4.9 years & -0.68 & -0.25 \\
\hline $5-10$ years & -0.66 & -0.32 \\
\hline$>10$ years & $1.13^{*}$ & 0.39 \\
\hline \multicolumn{3}{|l|}{ Type of previous } \\
\hline \multicolumn{3}{|l|}{ treatment } \\
\hline Surgical & -0.61 & -0.27 \\
\hline Conservative & 0.28 & -0.02 \\
\hline Both & -0.07 & -0.81 \\
\hline None & -0.29 & -0.41 \\
\hline
\end{tabular}

\section{Discussion}

The relevance of the holistic approach for keloid patients is essential to promote health, following an ethical and integrative model. The same aspects are recommended by the World Health Organization $(\mathrm{WHO})^{18}$.

Keloid patients present undeniable physical, social and psychological aftermaths. Even though most of them are exclusively focused on improvement of the scar characteristics (pigmentation, height, width, malleability) evaluated by a scale ${ }^{19}$.

In terms of surgery, keloids are not restricted to plastic surgery. In thoracic surgery, they have become a frequent complication as the thoracic wall has a high risk for occurrence of these lesions. Furthermmore, there is an increased incidence of coronary artery by-pass, even in Brazil|20,21. In gynecology and obstetrics, the presence of keloids is very frequent due to breast surgeries and Cesarean sections. It is worth mentioning that according to the age group affected and location of these scars, aftermath in the sexual sphere is relevant ${ }^{22}$. In bucomaxillofacial surgery, keloid formation is relatively frequent in Brazil, because of a high incidence of facial trauma due to traffic accidents ${ }^{23}$.

In dermatology, , keloids are becoming increasingly relevant. According to the Brazilian Society of Dermatology, in 2006, keloids were cited in the list of the most prevalent dermatological diseases cared for. They ranked $23^{\text {rd }}$ for patients in the 15-39 age groups, and $24^{\text {th }}$ in complaints of Afro-descendant patients. In this study, keloids were more frequent among women, Afro-descendants and the 30 year old age group, corroborating literature $25-28$.

Visible keloids are more frequent on the earlobe. This fact can be explained, according to the study by Lane et al. ${ }^{29}$, due to use of piercing by youngsters, that has become a public health issue.

In this study, patients with non-visible keloids presented a significantly higher score in the questionnaire QualiFibro physical domain, perhaps because most lesions located in the presternal area were from many years ago $(91.6 \%$ with more than a 10 year evolution) and were less responsive to treatments, pruritic and more painful. This affected the quality of life physical domain in comparison to keloids, with milder symptoms ${ }^{30}$.

Average disease duration was of 5.1 years. Chronicity

Table 2 - Correlation between the QualiFibro questionnaire score in relation to the psychological (satisfaction with appearance, shame of the disease, suffering experienced) and physical factors (pruritus, pain and movement restriction) assessed by the NVS:

NVS

\begin{tabular}{|c|c|c|c|c|c|c|c|}
\hline & & \multirow{2}{*}{\multicolumn{2}{|c|}{ SD }} & \multirow{2}{*}{ SE } & & & \\
\hline & & & & & $P$ & $P$ & MR \\
\hline \multirow{3}{*}{$\begin{array}{l}\text { QualiFibro } \\
\text { Questionnaire }\end{array}$} & Physical & $0.265^{* *}$ & $0.299 * *$ & $0.462^{* *}$ & $0.692^{* *}$ & $0.645^{* *}$ & $0.369 * *$ \\
\hline & Domain & & & & & & \\
\hline & $\begin{array}{c}\text { Psychological } \\
\text { Domain }\end{array}$ & $0.551 * *$ & $0.793 * *$ & 0.720 ** & $0.345^{* *}$ & $0.334^{* *}$ & $0.261^{* *}$ \\
\hline
\end{tabular}


influenced keloid patients directly. The QualiFibro physical domain score was significantly higher in patients who had the disease for more that 10 years.

Psychological factors (satisfaction with the appearance, shame of the disease and suffering experiencied) and physical (pruritus, pain and restriction of movements) of the NVS correlated positively with both Qualifibro domains. Besides supporting questionnaire validity, these data proved that keloid patient's evaluation should not be restricted to the physical level. On the contrary, it should include the psychological level, as these patients, in addition to being stigmatized ${ }^{31}$, live with an incurable disease.

This study has revealed a paradox. The QualiFibro psychological domain was not influenced by clinical factors. Thus, for example, a patient, with a visible keloid, submitted to a previous treatment and recurrent for more that 10 years, in the psychological domain showed a score similar to a patient with a non-visible keloid for less than one year, who had not been submitted to any treatment.

Therefore, it must be emphasized that specialists should not assume the entire treatment planning because of peculiarities of the disease. As such, influence of the clinical factors in the quality of life is not that obvious and real as it appears. Physical and psychological complaints reported by the keloid patients, sometimes considered less important by the specialists, could be of greater impact as perceived by the patient. The present study provides a perspective for the need of a multidisciplinary approach to these patients, which would include dermatologists, plastic surgeons, psychologists, psychiatrists and physiotherapists.

\section{Conclusion}

Results regarding the physical domain of the QualiFibro questionnaire were worst for patients with non-visible keloids as well as those with more than 10 years duration. The NVS physical and psychological factors referring to keloids have affected both physical and psychological domains of the quality of life.

\section{Conflict of interest: None}

\section{Resumo}

\section{QuaIS FATORES REALMENTE AFETAM A QUALIDADE DE VIDA DOS PORTADORES DE QUELOIDE?}

OBJETIVO. Avaliar quais fatores influenciam a qualidade da vida (QV) dos portadores de quelóide.

MÉtodos. Estudo envolvendo 102 pacientes, de ambos os gêneros, com idade entre 15 e 70 anos. Na avaliação inicial, os fatores clínicos referentes à visibilidade do queloide, tempo de evolução da doença, tratamento prévio, tipos de tratamento e recidiva foram catalogados. Posteriormente, os pacientes responderam ao questionário QualiFibro, composto pelos domínios físico e psicológico, específico para avaliar a QV dos portadores de quelóide, e a seis escalas visuais numéricas (EVN), sendo três escalas em relação a fatores psicológico (satisfação com a aparência, vergonha da doença e sofrimento vivenciado), e três escalas em relação a fatores físicos (prurido, dor e restrição de movimentos).
Resultados. A pontuação do domínio físico do questionário Qualifibro foi maior para os portadores de queloide em região não-visivel $(p<0,01)$ e com tempo de evolução maior que 10 anos $(p<0,049)$, refletindo piora em relação aos portadores com queloide em região visivel e com tempo de evolução de doença menor que 10 anos. Houve correlação positiva entre os fatores psicológico (satisfação com a aparência, vergonha da doença e sofrimento vivenciado) e físicos (prurido, dor e restrição de movimentos) avaliados pelas EVN's e ambos os domínios do questionário Qualifibro $(p<0,01)$.

Conclusão. O domínio físico do questionário Qualifibro foi pior nos portadores de quelóide não-visivel e naqueles com duração maior que 10 anos. Os fatores psicológicos e físicos das EVN's, implicados ao queloide, afetaram tanto o domínio físico quanto o domínio psicológico da QV. [Rev Assoc Med Bras 2009; 55(6): 700 - 4]

UnItermos: Queloide. Qualidade de vida. Questionários.

\section{References}

1. Silva JDT, Müller MC. Uma integração teórica entre psicosomática, stress e doenças crônicas de pele. Estud Psicol. (Campinas). 2007;24:247-56.

2. Martins GA, Arruda L, Mugnaini ASB. Validação de questionários de avaliação da qualidade de vida em pacientes de psoríase. An Bras Dermatol. 2004;79:521-35.

3. Finlay AY. Quality of Life measurement in dermatology: a practical guide. Br J Dermatol. 1997;136:305-14.

4. Halioua B, Beumont MG, Lunel F. Quality of life in dermatology. Int J Dermatol. 2000;39:801-6.

5. Wahl A, Hanestad BR, Wiklund I, Moum T. Coping and quality of life in patients with psoriasis. Qual Life Res. 1999;8:427-33.

6. McKenna KE, Stern R. The impact of psoriasis on the quality of life of patients from 16-center PUVA follow-up cohort. J Am Acad Dermatol. 1997;36(3 Pt 1):338-94.

7. Dreno B. Assessing quality of life in patients with acne vulgaris: implications for treatment. Am J Clin Dermatol. 2006;7:99-106.

8. Coghi S, Bortoletto MC, Sampaio SAP, Andrade Júnior HF, Aoki V. Quality of life is severely compromised in adult patients with atopic dermatitis in Brazil, especially due to mental components. Clinics. 2007;62:235-42.

9. Hon KL, Kam WY, Lam MC, Leug TF, Ng PC. CDLQI, SCORAD and NESS: are they correlated? Qual Life Res. 2006;15:1551-8.

10. Kent G, Al Abadie M. Psychologic effects of vitiligo: a critical incident analysis. J Am Acad Dermatol. 1996:35(6):895-8.

11. Koo J, Do J, Lee C. Psychodermatology. J Am Acad Dermatol. 2000;43:848-53.

12. Al-Attar A, Mess S, Thomassen JM, Kauffman CL, Davison SP. Keloid pathogenesis and treatment. Plast Reconstr Surg. 2006;117:286-300.

13. Bock O, Schmidd-Ott G, Malewski P, Mrowietz U. Quality of life of patients with keloid and hypertrophic scarring. Arch Dermatol Res. 2006;297:433-8

14. Martin D, Umraw N, Gomez M, Cartotto R. Changes in Subjective vs Objective Burn Scar Assessment Over Time: Does the Patient Agree with what we think? J Burn Care Rehabil. 2003;24:239-44.

15. Furtado FMP. Tradução para o idioma português, adaptação cultural e confiabilidade do Questionnaire of Quality of Life for Patients with Keloid and Hypertrophic Scarring [dissertação]. São Paulo: Escola Paulista de Medicina, Universidade Federal de São Paulo, 2008.

16. Guillemin F, Bombardier C, Beaton D. Cross-cultural adaptations of healthrelated quality of life measures: literatura review and proposed guidelines. J Clin Epidemiol. 1993;46:1417-32.

17. Siegel S, Castellan Júnior NJ. Estatística não-paramétrica para ciências do comportamento. 2a ed. São Paulo: Artmed; 2006.

18. WHOQOL Group. The World Health Organization Quality of Life Assessment (WHOQOL): Position paper from the World Health Organization. Soc Sci Med. 1995;41:1403-9. 
19. Mustoe TA, Cooter RD, Gold MH, Hobbs FD, Ramelet AA, Shakespeare PG, et al. International clinical recommendations on scar management. Plast Reconstr Surg. 2002;110:560-71.

20. Manuskiatti W, Fitzpatrick RE. Treatment response of keloidal and hypertrophic sternotomy scars: comparison among intralesional corticosteroid, 5-fluorouracil, and 585-nm flashlamp-pumped pulsed-dye laser treatments. Arch Dermatol. 2002;138:1149-55.

21. Almeida FF, Barreto SM, Couto BRGM, Starling CEF. Fatores preditores da mortalidade hospitalar e de complicaçöes per-operatórias graves em cirurgia de revascularizaçäo do miocárdio. Arq Bras Cardiol. 2003;80:41-60.

22. Tanos V, Anteby SO. Cesarean scar endometriosis. Int J Gynaecol Obstet. 1994;47:163-6.

23. Kreisner PE, Oliveira MG, Weismann R. Cicatrização hipertrófica e quelóides: revista de literatura e estratégias de tratamento. Rev Cir Traumatol BucoMaxilo-Fac. 2005;5:9-14

24. Sociedade Brasileira de Dermatologia. Censo Dermatológico. 2006 [cited 2008 Aug 7]. Available from :http://www.sbd.org.br/medicos/atualidade/ censo dermatologico2006.pdf.

25. Niessen FB, Spauwen PHM, Schalkwijk J, Kon M. On the nature of hypertrophic scars and keloids: a review. Plast Reconstr Surg. 1999;104:1435-58.

26. Alster TS, Tanzi EL. Hypertrophic scars and keloids. Am J Clin Dermatol. 2003;4:235-43.
27. Berman B, Bieley HC. Adjunct therapies to surgical management of keloids. Dermatol Surg. 1996;22(2):126-30.

28. Canary PCV, Filipo R. Papel da radioterapia no tratamento de quelóides-Análise retrospectiva de 267 casos. Rev Bras Cir. 1990;80:291-5.

29. Lane JE, Waller JL, Davis LS. Relationship between age of ear piercing and keloid formation. Pediatrics. 2005;115:1312-4

30. Muir IFK. On the nature of keloid and hypertrophic scars. Br J Plast Surg. 1990;43:61-9.

31. Ginsburg IH, Link BG. Psychosocial consequences of rejection and stigma feelings in psoriasis patients. Int J Dermatol. 1993;32:587-91.

32. van de Kar AL, Kreulen M, van Zuijlen PP, Oldenburger F. The results of surgical excision and adjuvant irradiation for therapy-resistant keloids: a prospective clinical outcome study. Plast Reconstr Surg. 2007;119:2248-54.

Artigo recebido: 21/09/08 Aceito para publicação: 25/03/09 